Supporting Information

\title{
Modulation of Semiconducting Behavior and a Change of Morphology upon Gelation of a Peptide Appended
} Naphthalenediimide

Kingshuk Basul, Biplab Mondal , Ayon Das Mahapatra², Nibedita Nandi ', Durga Basak², Arindam Banerjee ${ }^{1^{*}}$

${ }^{1}$ School of Biological Sciences, Indian Association for the Cultivation of Science, Jadavpur, Kolkata-700032, India. E-mail: bcab@,iacs.res.in

${ }^{2}$ School of Physical Sciences, Indian Association for the Cultivation of Science, Jadavpur, Kolkata-700032, India. 


\section{Instruments:}

NMR Experimets:All NMR studies were carried out on a Brüker DPX $400 \mathrm{MHz}$ and 500 $\mathrm{MHz}$ spectrometer at $300 \mathrm{~K}$.

Mass Spectrometry:Mass spectra were recorded on a Qtof Micro YA263 high-resolution mass spectrometer.

High Resolution Transmission Electron Microscopy:The morphology of the native hydrogel was investigated by using a high resolution transmission electron microscope. The samples were prepared by depositing a drop of the highly diluted aggregated and gel-phase materials onto a TEMgrid (300 mesh $\mathrm{Cu}$ grid) that was coated with Formvar and carbon film. Then, the grid was dried undervacuum at $30{ }^{\circ} \mathrm{C}$ for two days. Images were recorded on a JEOL electron microscope at an acceleratingvoltage of $200 \mathrm{kV}$.

UV/Vis spectroscopy: All the spectroscopic studies were done in a Cary-50 spectrophotometer.

Fluorescence study: The fluorescence spectra were obtained using a perkinelmerspectrofluorimeter.

X-ray diffraction study: X-ray diffraction study of xerogel materialswere carried out by using anX-ray diffractometer (Bruker D8 Advance) with a parallel beam optics attachment. The instrument wasoperated at a $35 \mathrm{kV}$ voltage and $30 \mathrm{~mA}$ current using $\mathrm{Ni}$-filtered $\mathrm{Cu} \mathrm{K}_{\alpha}$ radiation and was calibrated witha standard silicon sample. Samples were scanned from $1^{\circ}$ to $80^{\circ}(2 \theta)$ at the step scan mode (step size $0.016^{\circ}$, preset time $2 \mathrm{~s}$ ) and the diffraction patterns were recorded using a scintillation scan detector.

MALDI-TOF MS: MALDI-TOF MS analysis has been performed by using Applied Biosystems MALDI TOF/TOFAnalyzer in dithranol matrix.

I-V measurements: For I-V measurements, the DC currents were measured between 
twovacuum deposited $\mathrm{Al}$ electrodes (diameter $2 \mathrm{~mm}$ ) on the xerogel pellets under a certain bias voltage using Keithley source meter (model 2410). The dark I-V characteristics were measured after keeping the samples in dark for several hours. For photocurrent transient measurement, a xenon light source (model no. 66902; Newport Corp. USA) was used for light illumination for intervals of $5 \mathrm{~min}$ on and $5 \mathrm{~min}$ off.

Rheology:Rheological studies were carried out at a constant oscillatory frequency of $1 \mathrm{~Hz}$ at room temperature $\left(25^{\circ} \mathrm{C}\right)$. Rheological experiments were performed with an AR 2000 advanced rheometer (TA Instruments) using cone plate geometry in a Peltier plate. The plate diameter has $40 \mathrm{~mm}$, with a cone angle of 4 degrees. Rheological experiment has been performed using $1.2 \% \mathrm{w} / \mathrm{v}$ GDL containing and $1.1 \% \mathrm{w} / \mathrm{v} \mathrm{RuCl}_{3}$ containing hydrogels keeping fixed the gelator concentration within the gel matrix.

\section{Detail Synthetic procedures and Characterizations:}

Synthesis of NDIP [N, N'-Di (11-aminoundecanamido-L-tyrosine)-naphthalene-3,4:9,10tetracarboxylic acid diimide]:

The dipeptide11-aminoundecanamido-L-tyrosine $\left[\mathrm{NH}_{2}-\mathrm{AUDA}-\mathrm{Tyr}-\mathrm{COOH}\right]$, was synthesized by conventional solution phase methods using racemization free fragment condensation strategy. The Boc group was used for the $\mathrm{N}$-terminal protection and the C-terminal was protected as a methyl ester. Coupling was mediated by N, N'-dicyclohexylcarbodiimide and 1-hydroxybenzotriazole (DCC/ HOBt). C-terminal methyl group was deprotected by using aqueous sodium hydroxide. The final compounds were fully characterized by mass spectrometry, ${ }^{1} \mathrm{H}$ NMR spectroscopy $(400 \mathrm{MHz}$ and $500 \mathrm{MHz}),{ }^{13} \mathrm{C}$ NMR spectroscopy (100 $\mathrm{MHz}$ and $125 \mathrm{MHz}$ ), Mass spectrometry and $\mathrm{C}, \mathrm{H}, \mathrm{N}$ analysis.

\section{Synthesis of Boc-AUDA-OH $\quad\left[\left(\mathrm{CH}_{3}\right)_{3} \mathrm{CONH}\left(\mathrm{CH}_{2}\right)_{10}-\mathrm{COOH}\right]: 2.01 \quad \mathrm{~g}$ of $11-$} aminoundecanoic acid $(10 \mathrm{mmol})$ was taken in a round bottomed flask. Then $10 \mathrm{ml} 1(\mathrm{~N})$ 
$\mathrm{NaOH}, 10 \mathrm{ml}$ water and $20 \mathrm{ml}$ 1,4-dioxane were added to it and the solution was cooled to $0^{\circ} \mathrm{C}-5^{\circ} \mathrm{C} .2 .20 \mathrm{~g}(10.1 \mathrm{mmol})$ di-tert-butyl dicarbonate (Boc anhydride) was added to the reaction mixture and stirred for 10 hours at room temperature. Then volume of the solution was reduced to one third in vacuum. The resulting mixture was acidified with saturated $\mathrm{KHSO}_{4}$ solution and the aqueous layer was extracted with ethyl acetate $(3 \times 40 \mathrm{ml})$. The ethyl acetate extract was dried over anhydrous sodium sulfate and evaporated in vacuum to obtain the white powdered product.

Yield: $2.84 \mathrm{~g}(9.43 \mathrm{mmol}, 94.35 \%)$.

Synthesis of Boc-AUDA-Tyr-OMe $\left[\left(\mathrm{CH}_{3}\right)_{3} \mathrm{CONH}\left(\mathrm{CH}_{2}\right)_{10} \mathrm{CONH}-\mathrm{NH}-(\mathrm{L}) \mathrm{CH}\left(\mathrm{C}_{6} \mathrm{H}_{5} \mathrm{OH}\right)-\right.$ COOCH3]: $2.71 \mathrm{~g}(9.0 \mathrm{mmol})$ of Boc-AUDA-OH was dissolved in 12ml dry DMF and then cooled in an ice bath. H-Tyr-OMe was obtained by neutralization with saturated $\mathrm{Na}_{2} \mathrm{CO}_{3}$ from its hydrochloride salt and subsequent extraction with ethyl acetate. The ethyl acetate solution was then concentrated to $10 \mathrm{ml}$ and added to the DMF solution followed by addition of $1.25 \mathrm{~g}(9.26 \mathrm{mmol})$ of HOBt and $2.06 \mathrm{~g}(10.0 \mathrm{mmol})$ of $\mathrm{N}, \mathrm{N}^{\prime}$ - dicylohexylcarbodiimide (DCC). The reaction mixture was then allowed to come at room temperature and stirred for next $20 \mathrm{hr}$. The reaction mixture was then diluted with ethyl acetate and filtered to separate $\mathrm{N}, \mathrm{N}$-dicyclohexyl urea (DCU). The ethyl acetate layer was washed with $1(\mathrm{~N}) \mathrm{HCl}(3 \times 30$ $\mathrm{ml})$, brine $(2 \times 30 \mathrm{ml})$. The organic layer was dried over anhydrous sodium sulphate and evaporated to obtain the yellowish product. The product was purified through silica gel column chromatography using $15 \%$ ethyl acetate in pet ether as eluent to obtain the pure white product.

Yield: $3.61 \mathrm{~g}(7.55 \mathrm{mmol}, 83.7 \%)$.

\section{Characterization:}


${ }^{1} \mathrm{H}$ NMR $\left(500 \mathrm{MHz}, \mathrm{CDCl}_{3}\right.$, TMS, $\left.25^{\circ} \mathrm{C}\right): \delta 7.81(1 \mathrm{H}$, brs, $-\mathrm{OH}$ of Tyr residue), 6.91-6.90 $(2 \mathrm{H}, \mathrm{d}, \mathrm{J}=8 \mathrm{~Hz}, 2$ aromatic protons of Tyr ortho with respect to -OH group), 6.76-6.74 (2H, $\mathrm{d}, \mathrm{J}=8.5 \mathrm{~Hz}, 2$ aromatic protons of Tyr meta with respect to $-\mathrm{OH}$ group), 6.10-6.08 $(1 \mathrm{H}, \mathrm{d}, \mathrm{J}$ $=7.5 \mathrm{~Hz}, \mathrm{~N}-\mathrm{H}$ proton of peptide $), 4.85-4.81(1 \mathrm{H}, \mathrm{m}, \alpha-\mathrm{CH}$ of Tyr $), 4.68(1 \mathrm{H}, \mathrm{brs}, \mathrm{N}-\mathrm{H}$ of Nterminus), $3.70\left(1 \mathrm{H}, \mathrm{s},-\mathrm{OCH}_{3}\right), 3.08-2.94\left(4 \mathrm{H}, \mathrm{m}, \beta-\mathrm{CH}_{2}\right.$ of Tyr and $\alpha-\mathrm{CH}_{2}$ of AUDA), 2.17$2.14\left(\alpha-\mathrm{CH}_{2}\right.$ with respect to $\mathrm{C}=\mathrm{O}$ of AUDA), $1.55\left(2 \mathrm{H}, \mathrm{m}, \beta-\mathrm{CH}_{2}\right.$ of AUDA), $1.42(10 \mathrm{H}, \mathrm{m}, 5$ $\mathrm{CH}_{2} \mathrm{~s}$ of AUDA), 1.24 (4H, m, $2 \mathrm{CH}_{2} \mathrm{~s}$ of AUDA), 1.21 (9H, s, 3- $\mathrm{CH}_{3} \mathrm{~s}$ of Boc). ${ }^{13} \mathrm{C} \mathrm{NMR}$ $\left(125 \mathrm{MHz}, \mathrm{CDCl}_{3}, \mathrm{TMS}, 25^{\circ} \mathrm{C}\right): \delta 173.36,172.46,156.08,130.27,126.77,115.70,53.27$, $52.38,40.7,37.18,36.58,30.06,29.44,29.30,29.22,29.18,29.12,28.54,26.71,25.60$. HRMS: Calculated for $\mathrm{C}_{26} \mathrm{H}_{42} \mathrm{~N}_{2} \mathrm{O}_{6}$ : 478.3, Found: $479.2322(\mathrm{M}+\mathrm{H})^{+}, 501.2059(\mathrm{M}+\mathrm{Na})^{+}$, 517.1838 $(\mathrm{M}+\mathrm{K})^{+}$.Elemental analysis: Calculated: C-65.25, H-8.84, N-5.85, O-20.06, Found: C-64.9\%, H-9\%, N-5.5\%.

\section{Synthesis of Boc-AUDA-Tyr-OH $\left[\left(\mathrm{CH}_{3}\right)_{3} \mathrm{CONH}\left(\mathrm{CH}_{2}\right)_{10} \mathrm{CONH}-\mathrm{NH}-(\mathrm{L}) \mathrm{CH}\left(\mathrm{C}_{6} \mathrm{H}_{5} \mathrm{OH}\right)-\right.$} $\mathbf{C O O H}$ ]: $3.5 \mathrm{~g}(7.32 \mathrm{mmol})$ of Boc-AUDA-Tyr-OMe was taken in a round bottomed flask and dissolved in $50 \mathrm{ml}$ methanol. $15 \mathrm{ml}$ of $1(\mathrm{~N}) \mathrm{NaOH}$ was then added to it and kept under stirring for 6 hours. The progress of hydrolysis was monitored by thin layer chromatography (TLC). After the completion of the reaction, as indicated by TLC, the methanol was removed in vacuum. The aqueous part was then taken in $50 \mathrm{ml}$ water and washed with diethyl ether (2 $\times 30 \mathrm{ml}$ ). The remaining solution was acidified with $1(\mathrm{~N}) \mathrm{HCl}$ and extracted with ethyl acetate $(3 \times 40 \mathrm{ml})$. The ethyl acetate extract was dried over anhydrous sodium sulfate and evaporated in vacuum to obtain a white powdered product.

Yield: $3.3 \mathrm{~g}(7.11 \mathrm{mmol}, 97.05 \%)$.

\section{Characterization:}


${ }^{1} \mathrm{H}$ NMR (500 MHz, DMSO-d 6 , TMS, $\left.25^{\circ} \mathrm{C}\right): \delta 12.34(1 \mathrm{H}$, brs, COOH), $9.2(1 \mathrm{H}$, brs, $-\mathrm{OH}$ of Tyr), 7.99-7.98 (1H, d, J = 8 Hz, Peptide NH), 7.00-6.98 (2H, d, J = 8.5, aromatic protons of Tyr meta with respect to $-\mathrm{OH}), 6.72(1 \mathrm{H}, \mathrm{brs}, \mathrm{NH}$ of $\mathrm{N}$-reminus), 6.64-6.63 $(2 \mathrm{H}, \mathrm{J}=8 \mathrm{~Hz}$, aromatic protons of Tyr ortho with respect to $-\mathrm{OH}), 4.34-4.32(1 \mathrm{H}, \mathrm{m}, \alpha-\mathrm{CH}$ of Tyr), 2.93$2.7\left(4 \mathrm{H}, \mathrm{m}, \beta-\mathrm{CH}_{2}\right.$ of Tyr and $\alpha-\mathrm{CH}_{2}$ of AUDA),2.05-2.00 (4H, m, $2 \mathrm{CH}_{2}$ protons of AUDA), 1.41-1.36 (12H, m, $6 \mathrm{CH}_{2}$ protons of AUDA), 1.22-1.14 (13H, m, $3 \mathrm{CH}_{3} \mathrm{~s}$ of Boc and $2 \mathrm{CH}_{2} \mathrm{~s}$ of AUDA). ${ }^{13} \mathrm{C}$ NMR (100 MHz, DMSO-d 6 , TMS, $\left.25{ }^{\circ} \mathrm{C}\right): \delta 173.30,172.13,171.94,17027$, $155.84,155.56,129.91,127.72,114.87,77.24,59.71,53.60,36.04,35.07,29.46,28.98$, 28.84, 28.77, 28.71, 28.49, 28.24, 26.27, 25.17, 20.99, 20.70, 14.04.HRMS: Calculated for $\mathrm{C}_{25} \mathrm{H}_{40} \mathrm{~N}_{2} \mathrm{O}_{6} 464.289$, Observed: $487.3360(\mathrm{M}+\mathrm{Na})^{+}$. Elemental analysis: Calculated C-64.65 $\%, \mathrm{H}-8.68, \mathrm{~N}-6.03 \%$. Found: C-64.6\%, H-8.8\%, N-5.9\%.

\section{Synthesis of $\mathrm{H}_{2} \mathrm{~N}-\mathrm{AUDA}-\mathrm{Tyr}-\mathrm{OH}$ [ $\left.\mathrm{NH}_{2}\left(\mathrm{CH}_{2}\right){ }_{10} \mathrm{CONH}-\mathrm{NH}-(\mathrm{L}) \mathrm{CH}\left(\mathrm{C}_{6} \mathrm{H}_{5} \mathrm{OH}\right)-\mathrm{COOH}\right]$ : To} $1.5 \mathrm{~g}(3.23 \mathrm{mmol})$ of Boc-UNDA-Tyr-OH, $4 \mathrm{ml}$ of trifluoroacetic acid (TFA) was added and the progress of the reaction was monitored by TLC. After $8 \mathrm{~h}$, TFA was removed under vacuum. The residue was dissolved into water $(10 \mathrm{ml})$ and neutralised by adding aqueous ammonia solution. After that total solution was transferred into a $50 \mathrm{~mL}$ of falcon tube. Water was removed out from this solution under vacuum to get a white mass.

Yield: $0.8 \mathrm{~g}(2.3 \mathrm{mmol}, 67 \%)$.

\section{Characterization:}

${ }^{1} \mathrm{H}$ NMR (400 MHz, DMSO-d 6 , TMS, $\left.25^{\circ} \mathrm{C}\right): \delta 8.45(1 \mathrm{H}$, brs, Tyr $-\mathrm{OH}), 7.27-7.25(1 \mathrm{H}, \mathrm{d}, \mathrm{J}$ $=6.8 \mathrm{~Hz}$, peptide $\mathrm{NH}), 6.91-6.9(2 \mathrm{H}, \mathrm{d}, \mathrm{J}=8 \mathrm{~Hz}$, aromatic protons of Tyr meta with respect to $-\mathrm{OH}), 6.6-6.57(2 \mathrm{H}, \mathrm{d}, \mathrm{J}=8 \mathrm{~Hz}$, aromatic protons of Tyr ortho with respect to $-\mathrm{OH}), 4.08$ $4.07\left(1 \mathrm{H}, \mathrm{m}, \alpha-\mathrm{CH}\right.$ of Tyr), 2.94-2.91 (2H, m, $\alpha-\mathrm{CH}_{2}$ of AUDA with respect to $\left.\mathrm{NH}_{2}\right), 2.74-$ $2.70\left(2 \mathrm{H}, \mathrm{m}, \beta-\mathrm{CH}_{2}\right.$ of Tyr), $2.00\left(2 \mathrm{H}, \mathrm{m}, \alpha-\mathrm{CH}_{2}\right.$ of AUDA with respect to $\left.\mathrm{C}=\mathrm{O}\right), 1.52-1.21$ 
$\left(14 \mathrm{H}, \mathrm{m}, 7-\mathrm{CH}_{2}\right.$ s of AUDA). ${ }^{13} \mathrm{C}$ NMR (100 MHz, DMSO-d 6 , TMS, $\left.25{ }^{\circ} \mathrm{C}\right): \delta 174.07$, $171.00,165.44,155.49,129.97,128.83,114.51,55.08,36.69,35.52,28.32,28.04,26.92$, 25.52, 25.11. HRMS: Calculated for $\mathrm{C}_{20} \mathrm{H}_{32} \mathrm{~N}_{2} \mathrm{O}_{4}$ : 364.236, Found: $364.8441(\mathrm{M}+\mathrm{H})^{+}$, $386.8202(\mathrm{M}+\mathrm{Na})^{+}$. Elemental analysis: Calculated: C-65.91\%, H-8.85\%, N-7.69\%, O17.56\%, Found: C-66.2\%, H-9.1\%, N-8.1\%.

\section{Synthesis of NDIP $\left.\left[\mathrm{C}_{10} \mathrm{H}_{4}\left\{\mathrm{COON}\left(\mathrm{CH}_{2}\right)_{10} \mathrm{CONH}-\mathrm{NH}-(\mathrm{L}) \mathrm{CH}\left(\mathrm{C}_{6} \mathrm{H}_{5} \mathrm{OH}\right)-\mathrm{COOH}\right)\right\}_{2}\right]\left[\mathrm{N}^{\prime} \mathrm{N}^{\prime}-\right.$}

Di (11-aminoundecanamido-L-tyrosine)-naphthalene-3,4:9,10-tetracarboxylic acid

diimide]: $\mathrm{H}_{2} \mathrm{~N}-\mathrm{AUDA}-\mathrm{Tyr}-\mathrm{OH}(0.36 \mathrm{~g}, 1.10 \mathrm{mmol})$ and naphthalenedianhydride $(0.130 \mathrm{~g}, 0.5$ mmol) were placed in a round-bottomed flask along with excessimidazole and the reaction mixture was stirred for $12 \mathrm{~h}$ at $140{ }^{\circ} \mathrm{C}$ under nitrogenous atmosphere. The heating was then stopped and water was added to the reaction mixture followed by acidification. This whole mixture was then kept at $4{ }^{\circ} \mathrm{C}$ for 2 hours to get a dark brown precipitate. This dark brown solid was then separated by filtration with under suction pump. The product was further purified by column chromatography by using silica gel as stationary phase and $3 \% \mathrm{CH}_{3} \mathrm{OH}$ in $\mathrm{CHCl}_{3}$ as eluent.

${ }^{1} \mathrm{H}$ NMR (400 MHz, DMSO-d 6 , TMS, $25^{\circ} \mathrm{C}$ ): $\delta 12.52(2 \mathrm{H}$, brs, COOH of both ends), 12.10 (2H, brs, $\mathrm{OH}$ group of Tyr), 8.66-8.59 (4H, m, aromatic protons of naphthalene core), 7.59$7.93(2 \mathrm{H}, \mathrm{d}, 7.6 \mathrm{~Hz}$, peptide $\mathrm{NH}), 6.97-6.95(4 \mathrm{H}, \mathrm{d}, \mathrm{J}=8.4 \mathrm{~Hz}$, aromatic protons of Tyr meta with respect to $-\mathrm{OH}), 6.61-6.59(4 \mathrm{H}, \mathrm{d}, \mathrm{J}=8 \mathrm{~Hz}$, aromatic protons of Tyr ortho with respect to $-\mathrm{OH}), 4.29-4.28\left(2 \mathrm{H}, \mathrm{m}, \alpha-\mathrm{CH}\right.$ of two Tyr), 4.06-4.02 (4H, m, $\alpha-\mathrm{CH}_{2}$ of two AUDA units with respect to $\left.\mathrm{NH}_{2}\right), 2.91-2.66\left(4 \mathrm{H}, \mathrm{m}, \beta-\mathrm{CH}_{2}\right.$ of two Tyr residues), 2.03-1.98 (4H, m, $\alpha-$ $\mathrm{CH}_{2}$ of two AUDA units with respect to $\left.\mathrm{C}=\mathrm{O}\right), 1.64-1.63\left(4 \mathrm{H}, \mathrm{m}, \beta-\mathrm{CH}_{2}\right.$ of two AUDA units with respect to $\left.\mathrm{NH}_{2}\right), 1.41-1.14\left(28 \mathrm{H}, \mathrm{m}\right.$, intervening $7 \mathrm{CH}_{2}$ of two AUDA units). (Figure $\mathrm{S} 1$ below $)^{13} \mathrm{C}$ NMR (100 MHzDMSO-d 6 , TMS, $\left.25^{\circ} \mathrm{C}\right): 173.26,172.00,163.07,162.41,155.74$, $130.27,129.28,129.55,127.69,127.22,126.64,126.56,126.21,126.12,126.04,125.91$, 
$114.87,114.78,53.58,51.57,35.99,35.03,28.81,28.79,28.70,28.64,28.41,27.28,26.44$, 25.11, 25.02. (Figure S2 below) MALDI-TOF mass: Calculated for, $\mathrm{C}_{54} \mathrm{H}_{64} \mathrm{~N}_{4} \mathrm{O}_{12}$ : 960.452 , Found: $983.321(\mathrm{M}+\mathrm{Na})^{+}, 999.338(\mathrm{M}+\mathrm{K})^{+}$. (Figure S3 below) Elemental analysis: Calculated: C-67.48\%, H-6.71\%, N-5.83\%, O-19.98\%, Found: C-67.3\%, H-7.1\%, N-6.1\%.

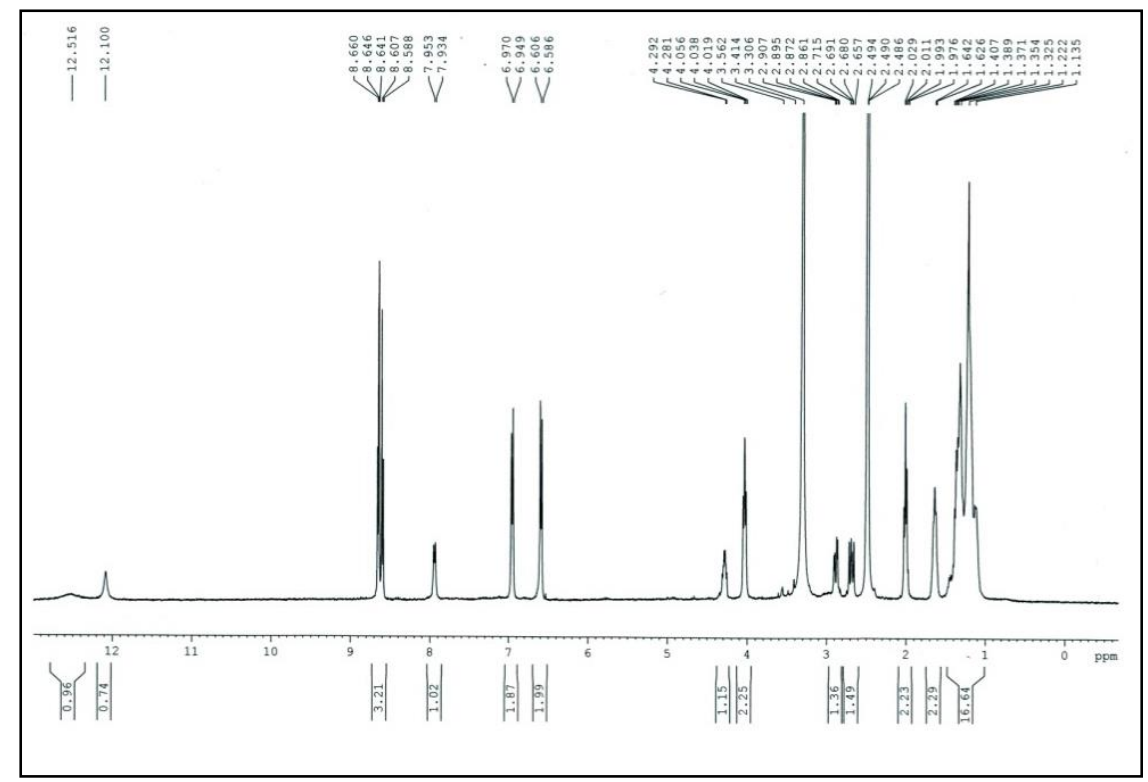

Figure S1: ${ }^{1} \mathrm{H}$ NMR spectrum of NDIP.

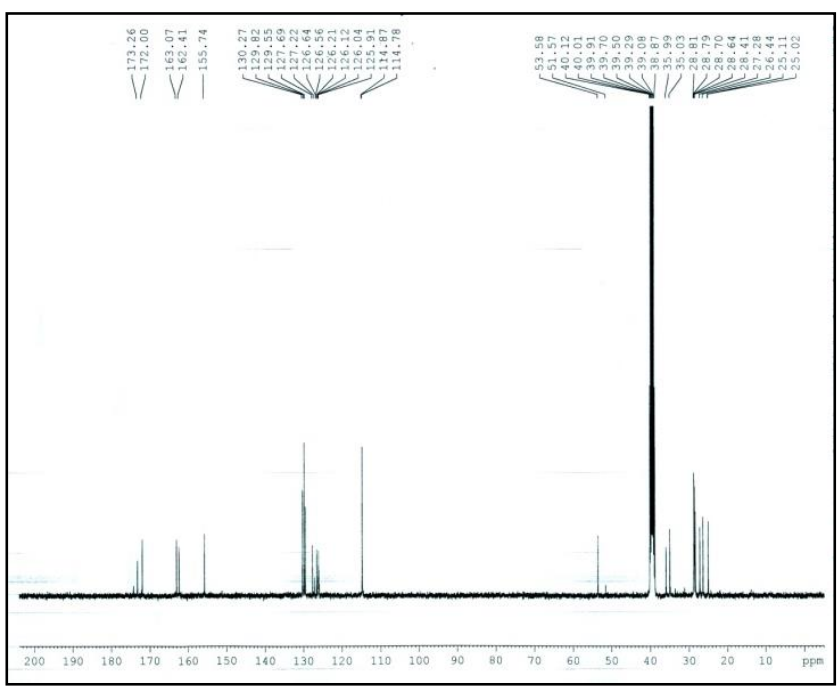

Figure S2: ${ }^{13} \mathrm{C}$ NMR spectrum of NDIP. 


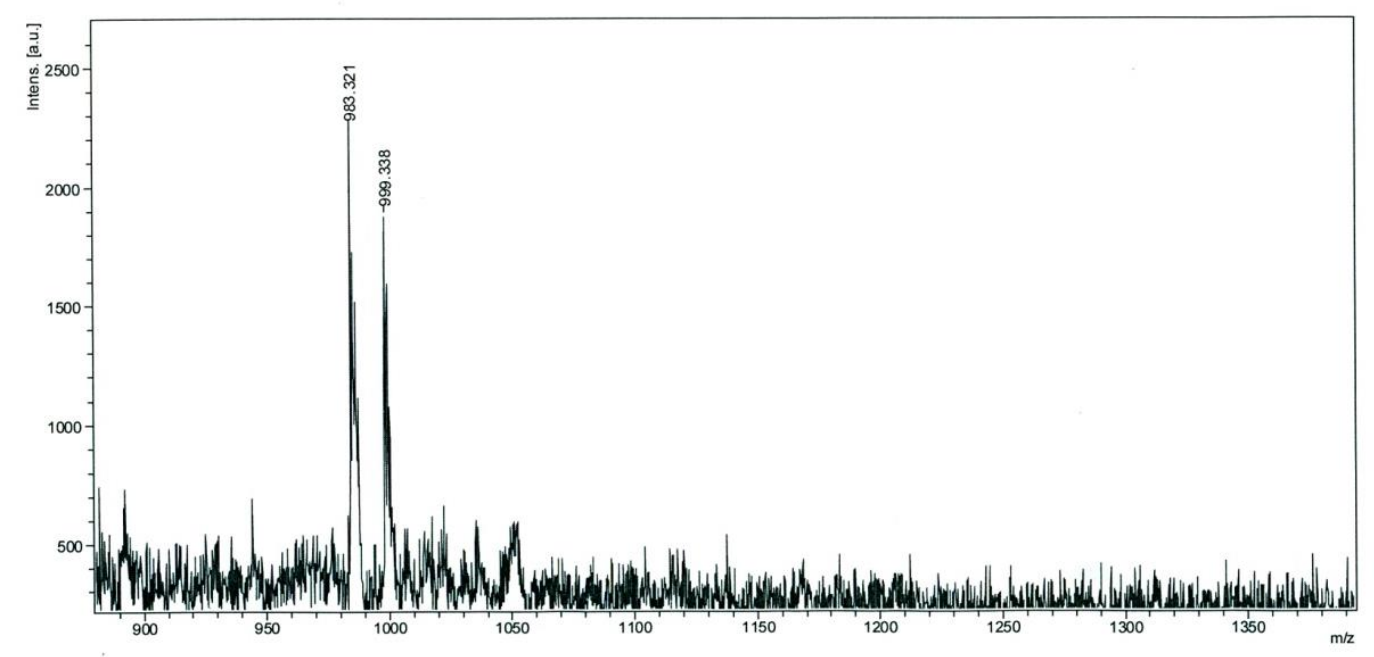

Figure S3: MALDI-TOF spectrum of NDIP.
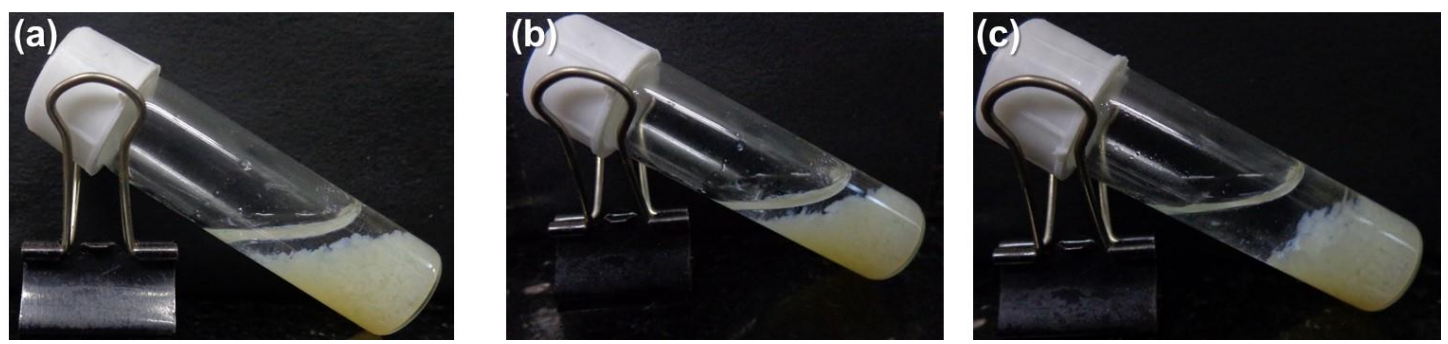

Figure S4: Solutions of NDIP after addition of (a) $\mathrm{HCl}$, (b) $\mathrm{H}_{2} \mathrm{SO}_{4}$ and (c) $\mathrm{CH}_{3} \mathrm{COOH}$ solutions into the aggregated solution of NDIP in $\mathrm{pH} 7.5$ phosphate buffer. 

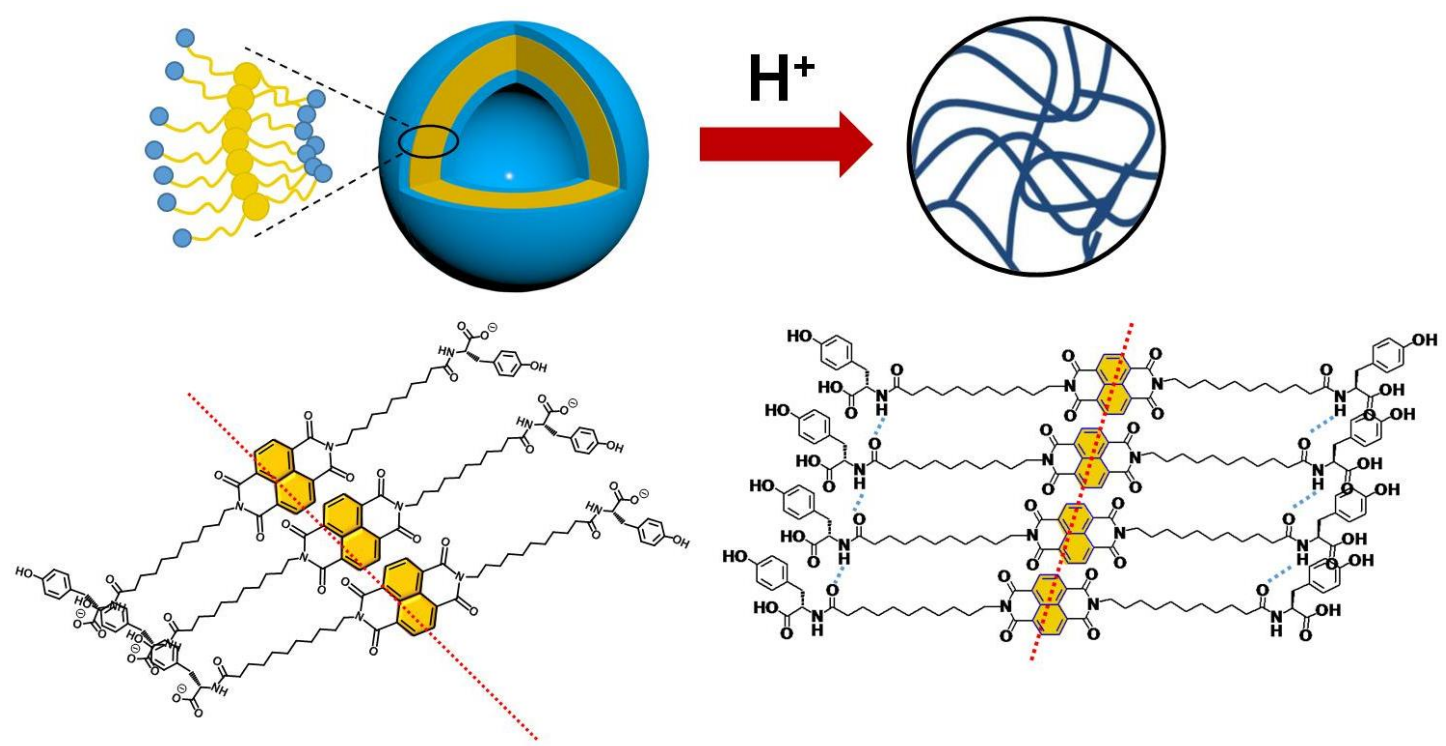

Figure S5: Tentative model of sphere to fibre transformation based on HR-TEM, FT-IR and XRD studies. 